\title{
FUSION CAPABILITY OF RAT EMBRYONIC ORAL TISSUE IN VITRO
}

\author{
A. N. Goss, J. W. BodNer and J. K. AverY \\ Department of Oral Biology, University of Michigan School of \\ Dentistry, Ann Arbor, Michigan 48104, U.S.A.
}

\begin{abstract}
Summary-The premise that only an area limited to the medial edge of the palatal shelves has the potential to fuse was studied. Three series of 15 day, $16 \mathrm{hr}$ embryo palates and tongues were cultured in vitro for $72 \mathrm{hr}$. In the first series the middle third of the face was cultured to study palatal shelf fusion. In the second the tongue was left in situ between the shelves and in the third littermate pairs of tongues were placed with their lateral borders in contact in the culture dishes. It was found that 16 of 20 palatal shelves fused, 39 of $\mathbf{4 0}$ palate to tongues fused, and fusion occurred between all the tongue pairs. In the first group the 4 shelves that failed to fuse were not in contact. Of group two, 32 areas of fusion revealed mesenchyme penetration and 7, lamination, there being mesenchymal penetration of all the tongue pairs. It is therefore concluded that fusion is not limited to a specific area of the palatal shelves but is a general property of oral tissues of embryonic rats of this age. Further it was found that for fusion to occur these tissues must be in close and quiescent contact.
\end{abstract}

\section{INTRODUCTION}

CLEFT palate is a common malformation of man and has been the subject of much investigation. The majority of the investigative efforts have utilized the experimental approach in animals. The multiplicity of studies is due in part to the fact that palatal cleft may result from a number of different factors acting at a number of different times in development. One such factor which may cause cleft palate is failure of the palatal shelves to fuse.

The process of palatal fusion may be studied in an isolated manner by the technique of in-vitro organ culture of palatal shelves. It has been shown both grossly and histologically that in vitro palatal fusion is comparable to the in-vivo process (MORIARTY, Weinstein and Gibson, 1963; Konegni et al., 1965; RfeVe, Porter and Lefkowitz, 1966). On this basis, extensive in-vitro studies of the morphology and properties of the tissues involved in the fusion process have been undertaken in both Sprague-Dawley rats (Pourtois, 1966, 1968; MYers, Petrakis and Lee, 1967) and A/Jax mice (Vargas, 1967).

The potentiality of oral tissues to fuse has been described as being confined solely to the medial edge of the palatal shelf (Pourtois, 1968; Meyers, Petrakis and Lee, 1968). Further, this potentiality to fuse is not present at all stages of development. In-vitro studies have shown that with Sprague-Dawley rats the palatal shelves gain the potentiality to fuse together at least $36 \mathrm{hr}$ (at age 15 days, $0 \mathrm{hr}, 15 / 0$ ) prior to the actual in-vivo time of fusion at age 16/12 (PouRTOIS, 1966). 
On the 15th day, the palatal shelves are vertical and separated from each other by the tongue. They remain in this position until shelf rotation occurs a few hours prior to actual fusion. Hence, shelves with the potentiality to fuse remain in close contact but without fusing to the tongue for at least $30 \mathrm{hr}$ (Fig. 1). The failure of the tongue to fuse with the palatal shelves, despite their proximity, may be due to an inherent affinity between one palatal shelf and another and a rejection of tongue. An alternative explanation may be that fusion is a generalized property of epithelium-covered mesenchyme provided that certain, though undefined, local requirements are met.

Thus the purpose of this investigation was to study whether fusion is a specific property of areas of palatal shelves or a generalized property of oral epithelium-covered mesenchyme under a specific set of conditions.

\section{MATERIALS AND METHODS}

\section{Experimental animal preparation}

Mature Sprague-Dawley rats were kept on a diet of stock rat pellets and water ad libitum under conditions of controlled light and temperature. Each breeding night, pairs of female rats were placed in a cage with one male rat at midnight and separated again at $8 \mathrm{a} . \mathrm{m}$. next day. The assumed time of conception was take as half way through the breeding period, consequently the age of each litter was known to within a maximum of $\pm 4 \mathrm{hr}$. The day of separation was called day 0 . On day 15, all rats were tested for pregnancy by abdominal palpation. Pregnant rats were killed by decapitation at 8 p.m. on the 15 th day. Hence all material used on this study was aged 15 days $16 \mathrm{hr} \pm 4 \mathrm{hr}$ at time of explantation.

The abdomen was shaved, swabbed with alcohol and the peritoneal cavity opened by a sterile technique. The uterus was removed and placed in a large sterile petri dish. Individual embryos each in their amniotic sac were removed from the uterus and placed in separate small sterile petri dishes containing $0.5 \mathrm{ml}$ of sterile Hank's buffered salt solution.

\section{In vitro culture}

After dissection, all preparations were grown under the same simple standardized conditions. The technique used Leibovitz L-15 medium in free gaseous exchange with the environment (MeYers et al., 1967). The dissected tissues were placed on a millipore filter, which in turn rested on a metal grid in a plastic organ culture dish (Fig. 2).

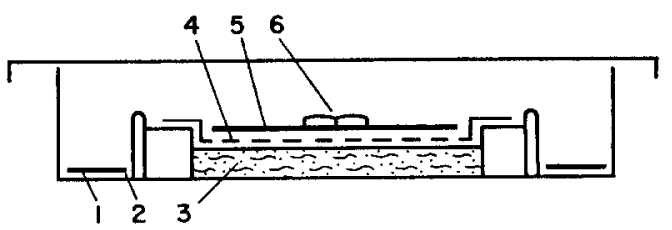

Fig. 2. Cross section of a culture dish. (1) Filter paper saturated with sterile water. (2) Water well. (3) Media in media well. (4) Metal grid. (5) Millipore filter. (6) Tissue. 
The cultures were maintained at $37 \cdot 0 \pm 0 \cdot 5^{\circ} \mathrm{C}$, in free exchange with the atmosphere, for $72 \mathrm{hr}$. The media was replaced after $36 \mathrm{hr}$. After incubation, the preparation still resting on the millipore filter was placed in 4 per cent glutaraldehyde for $24 \mathrm{hr}$. The tissues were then embedded in paraffin, serially sectioned in the frontal plane at $8 \mu$ and stained with haemotoxylin and eosin. The only departure from standard histologic technique was that all tissues were placed in eosin for 2 min between the 70 and 80 per cent alcohols during dehydration following fixation. This superficial staining greatly facilitated the subsequent orientation of the tissues for sectioning.

\section{Dissections}

Three different preparations were used, and all were obtained under strict sterile conditions using scalpels with number 15 blades under a dissecting stereoscope.

The Group I preparation was the control preparation and demonstrated palatal fusion. The preparation consisted essentially of the middle third of the face and was obtained by a previously described dissection procedure (MORIARTY et al., 1963). In this procedure, the head is removed from the body and then the tongue and mandible are removed from the remainder of the face. The brain and cranial vault are then excised with an incision parallel to the roof of the mouth at the level of the eyes and lastly the excess pharyngeal tissue posterior to the palatal shelves is removed. The resulting preparation consists of the snout and upper lip, nasal septum, alveolar ridges and palatal shelves and is approximately $4.5 \mathrm{~mm}$ in anterior posterior length, $4 \mathrm{~mm}$ in width and $1.5 \mathrm{~mm}$ in thickness. The preparations were placed with the nasal surface contacting the millipore filter and grown in culture for $72 \mathrm{hr}$. Twenty such preparations were obtained (Fig. 3).

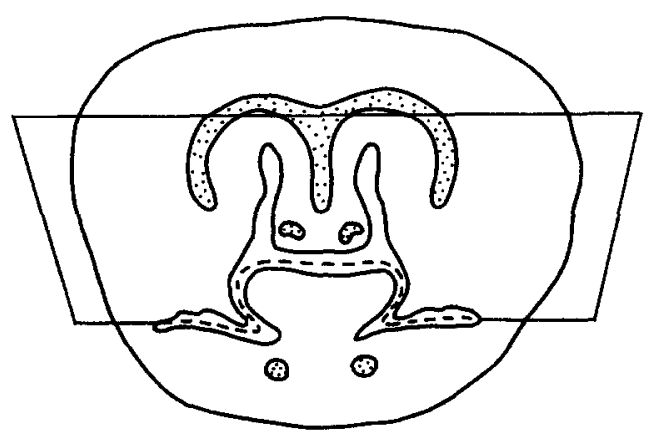

FIG. 3. Group I preparation. Frontal section.

The Group II preparation was essentially similar to Group I excepting that the tongue was left in situ and was not removed with the mandible. Hence the tongue was in its normal position for this age, between the palatal shelves, partly in the oral cavity and partly in the nasal cavity. Twenty such preparations were obtained from 2 litters (Fig. 4). 


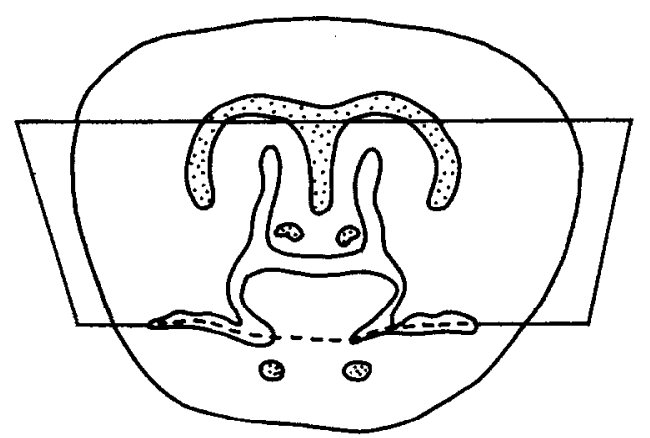

FrG. 4. Group II preparation. Frontal section.

The Group III preparation consisted of the tongues of a pair of littermates placed with their lateral borders in contact, with the dorsal side uppermost. Ten pairs of tongues were obtained from the same litters as Group I. The remaining 10 pairs were from 2 litters, the palatal shelves of which were used as normal controls for subsequent experiments (Fig. 5).

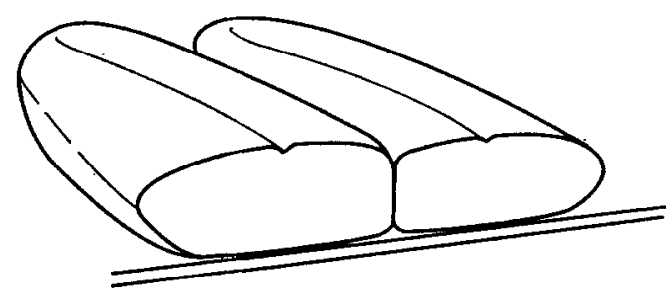

FIG. 5. Group III. Tongue pair.

\section{RESULTS}

Examination of Group I, the control group, showed 16 out of the 20 explants with fusion of palatal shelf to palatal shelf. The 4 shelves that failed to fuse were not in contact. In the present series of experiments, fused is the term used to describe the situation where an epithelial barrier remained intact between the mesenchymal tissues or where this barrier had been penetrated by the mesenchymal tissue. Hence the term fused is subclassified into laminated and penetrated. Unfused described the situation where the tissues were apart. Each preparation was classified according to the most advanced stage of fusion attained (Fig. 6).

There were at least 40 potential areas of fusion in the 20 explants in the Group II series, since each palatal shelf was in contact with the lateral surface of the tongue. Palate to tongue fusion occurred in 39 of the possible 40 situations, one failing to fuse. Of the fused group, 32 showed mesenchymal penetration and seven were laminated. The fusion site between tongue and palate was in most cases the lateral border of the tongue to the medial border of the shelf. However, in some instances the tongue was 
angled between the shelves and fusion occurred between the tongue and either the nasal or the oral surface of the palatal shelf (Figs. 7 and 8).

Fusion with mesenchymal penetration occurred between all of the 20 Group III tongue pairs. Characteristically, fusion between the tongue pairs commenced at the ventral surface in contact with the nutrient supply and proceeded dorsally (Figs. 9, 10 and 11). The results are summarized in Table 1.

TABle 1. TOtAL Results

\begin{tabular}{lccccc}
\hline Group & Fusion sites & Unfused & $\begin{array}{c}\text { Fused } \\
\text { laminated }\end{array}$ & $\begin{array}{c}\text { Fused } \\
\text { penetrated }\end{array}$ & $\begin{array}{c}\text { Fused } \\
\text { total }\end{array}$ \\
\hline $\begin{array}{c}\text { I } \\
\text { palate/palate } \\
\text { II }\end{array}$ & 20 & 4 & - & 16 & 16 \\
palate/tongue \\
$\begin{array}{l}\text { III } \\
\text { tongue/tongue }\end{array}$ & 40 & 1 & 7 & 32 & 39 \\
\hline
\end{tabular}

Fusion of epithelium and adjacent mesenchyme of the tongue to tongue, and the tongue to palatal shelf, appeared similar to the zone of fusion of palatal shelf to palatal shelf. The first stage of this process was definite adherence of the contacting epithelial layers. This produced a definite laminated epithelial barrier. This type of fusion was demonstrated in that they did not pull apart during histological preparation. It was found in the present study that this lamination stage did not persist, the 2 distinct epithelial layers becoming continuous, and less regular in thickness. Then the epithelial barrier appeared to be disrupted and the adjacent mesenchyme intermingled with that of the opposing tissue. The fusion process did not seem to be marked by any areas of cellular proliferation or specifilization on a histologic basis. More specifically we did not note any thickening of the epithelium in the potential area of fusion of either the palatal shelf pairs, shelf and tongue pairs, or tongue pairs. The observation of thickening of epithelium in the prospective area of in-vitro fusion of palatal shelves has been previously reported (PourToIs, 1968). The site of fusion appeared to be the site of contact. No differences in cellular morphology or behaviour in the fusion process were seen between the different areas of tissue involved.

All the tissues appeared normal and healthy after $72 \mathrm{hr}$ of culture. There was no evidence of pyknosis or central breakdown of the fairly large preparations of Group I and II. Differentiation of blood vessels in the tongue and palate and also muscle cells in the tongue also occurred in vitro. A distinct transverse muscle layer formed in the tongue just deep to the dorsal surface. Specialized oral structures such as minor mucous salivary glands in the base of the tongue and tooth buds in the alveolar processes showed continued development. 


\section{DISCUSSION}

Under the conditions of this in-vitro experiment, it was evident that the property of fusion is not confined to the palatal shelves, though other workers have reported fusion occurring only between medial edges of palatal shelves (PoURTOIs, 1968; MYERs et al., 1968). Our experiment demonstrates the similar abilities of epitheliumcovered mesenchymal tissue of oral origin to fuse together; palatal shelf to palatal shelf tongue to palatal shelf and tongue to tongue. In-vitro glossopalatine and tongue to tongue fusion has not been previously described. The more generalized potentiality to fuse has also been demonstrated between palatal shelves and eyelids under in vitro conditions (VARGAS, 1968).

In-vivo fusion of the palate to the tongue in both experimental animals and man is an extremely rare event. Possible adhesions between tongue and palatal shelves have been described in 14-day old mice embryos (CODDINGTON and VISSER, 1962). This must have been a transient event or an effect of tissue fixation as it did not interfere with normal palatal closure. No connection between tongue and palate was ever demonstrated in older embryos of the same series. Glossopalatine fusion is part of a syndrome of defects found in embryos of pregnant rats treated with chlorcyclizine, which is a tranquilizer of the meclizine group. Other orofacial defects in this syndrome are severe brachygnathia and microstomia. In most instances the tongue and palate adhered together though in some areas epithelial breakdown and mesenchymal penetration occurred (STEFFEK, KING and DERR, 1966). In humans, less than 20 cases of glossopalatine fusion have been reported (SPIVACK and BENNETT, 1968). Reported cases range from the presence of thin fibrous bands (HAYwARD and AVERY, 1957) to complete union with bony tissue present joining the tongue and maxilla. Invariably these cases have other defects including malformation of the extremities, micrognathia and facial nerve paralysis.

The differences between in-vitro and in-vivo behaviour may be of importance in determining some of the requirements of normal fusion. On the basis of our in-vitro experiments we suggest that two factors are of vital importance. First, the tissues involved in the fusion process must be in very close contact and secondly, they must be in immobile or quiescent contact. It was observed that, where the tissues were not in close contact, fusion did not occur, as was seen in the Group I, palatal shelf to palatal shelf control series. Also in the Group II, tongue to palatal shelf series, fusion occurred at the point of contact, even in the few cases where the tongue was at an angle between the shelves. Again in Group III, the tongue pairs were placed in tight contact at the beginning of the culture period and fusion occurred in all cases.

Mobility is one of the essential differences between the in-vivo and in-vitro situation. In vivo, the necessary neuroanatomic pathways and muscular differentiation for orofacial movement are present prior to palatal shelf fusion in the rat (SWENSEN, 1926). Distinct tongue thrusting and jaw movements have been observed and recorded in rats of embryonic age 16/0 days, which is prior to palatal shelf rotation from the vertical to the horizontal position (BODNER, CHENEY and AVERY, 1968). It is perhaps significant that in-vivo glossopalatine fusion occurs in rats treated with the tranquilizer chlorcyclizine. This may be due to either inhibition of movement or from a 
teratogenic effect of the drug on the tissues. Finally, in the few reported cases of human glossopalatine ankylosis, some have been associated with paralysis of the muscles supplied by the facial nerve but the status of the motor control of the tongue has not been described. Hence there is at least suggestive evidence that glossopalatine fusion does not occur in the normal in-vivo situation because of the lack of quiescent contact between the tongue and palatal shelves.

Acknowledgements - This investigation was supported by Grant DE-02774 from the National Institutes of Health, Bethesda, Maryland. We wish to recognize personal communication with Dr. VARGas who clarified some technical procedures carried out by himself, Dr. Narbaitz and Dr. Kraus, of the Cleft Palate Research Center, University of Pittsburgh, School of Dental Medicine. We also wish to acknowledge the assistance of Dr. R. H. KAHN, Department of Anatomy, Medical School, University of Michigan.

\begin{abstract}
Résumé-Le fait qu'une seule région bien limitée de l'extrémité mésiale des lames palatines a la possibilité de fusionner a été étudié. Trois séries de palais et langues, âgés de 15 jours et 16 heures, ont été cultivées in vitro pendant 72 heures. Dans la première série, le tiers moyen de la face est mis en culture pour étudier la fusion des lames palatines. Dans la seconde série, la langue est laissée in situ entre les lames et, dans la troisième série, les bords latéraux de paires de languessont placées en contact dans des boites de cultures. Seize sur 20 lames palatines fusionnent; 39 sur 40 palais fusionnent aux langues, tandis que toutes les paires de langues fusionnent. Dans le premier groupe, les quatre lames, qui n'ont pas fusionné, n'étaient pas en contact. Dans le second groupe, 32 régions de fusion présentent une pénétration mésenchymateuse et sept formations lamellaires. Dans le dernier groupe, une pénétration mésenchymateuse a été notée dans toutes les paires de langues. On peut donc conclure que la fusion n'est pas limitée à une région particulière des lames palatines, mais est une propriété générale des tissus buccaux des embryons de rats étudiés. La réalisation de la fusion de ces deux tissus nécessitent un conlact intime.
\end{abstract}

Zusammenfassung-Es wurden Untersuchungen über die Annahme durchgeführt, da $\beta$ lediglich ein auf die mesiale Spitze der palatinalen Gaumenfortsätze begrenzter Bezirk das Potential zur Fusion besitzt. 3 Serien von $15 \mathrm{Tg}$. und 16 Std. alten embryonalen Gaumen und Zungen wurden in vitro 72 Std. lang kultiviert. Bei der ersten Serie wurde das mittlere Gesichtsdrittel kultiviert, um die Fusion der Gaumenfortsätze zu studieren. Bei der zweiten Serie wurde die Zunge zwischen den Fortsätzen in situ belassen. In der dritten Serie wurden die Zungen von Paarlingen aus dem gleichen Wurf mit ihren lateralen Rändern im Kontakt auf die Kulturplatten plaziert. Eine Fusion trat bei 16 von 20 Gaumenfortsätzen, in 39 von 40 Fällen zwischen Gaumen und Zunge und bei allen Zungenpaaren ein. Bei den 4 Gaumenfortsätzen, die in der ersten Gruppe nicht, zusammenwuchsen, fehlte der Kontakt. Bei der Gruppe 2 zeigten 32 Fusionsbezirke das Eindringen von Mesenchym und 7 Lamination; bei allen Zungenpaaren war eine mesenchymale Vereinigung vorhanden. Daraus wird geschlossen, daB die Fusion nicht an einen bestimmten Bezirk der Gaumenfortsätze gebunden ist; vielmehr ist dies eine allgemeine Eigenschaft der Mundhöhlengewebe embryonaler Ratten dieses Alters. Weiterhin wurde gefunden, daß diese Gewebe zur Fusion in engenem und unbeweglichem Kontakt sein müssen.

\title{
REFERENCES
}

Bodner, J., Cheney, C. and Avery, J. K. 1969. Embryonic Movements in the Rat during Palatal Closure. $16 \mathrm{~mm}$ film. The University of Michigan, School of Dentistry, Ann Arbor, Michigan.

Coddington, D. J. and Visser, R. L. 1962. A study of the etiology of cleft palate formation in mice. 71 p. typed thesis. The University of Michigan, School of Dentistry, Ann Arbor, Michigan. 
HAYWARD, J. R. and Avery, J. K. 1957. A variation in cleft palate. J. Oral Surg. 15, 320-326.

Konegni, J. S., Chan, B. C., Moriarty, T. M., Weinstein, S. and Gibson, R. D. 1965. A comparison of standard organ culture and standard transplant tcchniques in the fusion of the palatal processes of rat embryos. Cleft Palate J. 2, 219-228.

Moriarty, T. M., Weinstern, S. and Gibson, R. D. 1963. The development in vitro and in vivo of fusion of the palatal processes of rat embryos. J. Embryol. exp. Morph. 11, 605-619.

Myers, G. S., Petrakis, N. L. and Lee, M. 1967. Cultivation of embryonic rat palates in defined and semi-defined media. Archs oral Biol. 12, 565-567.

Myers, G. S., Petrakis, N. I. and LeE, M. 1968. Factors influencing fusion of rat palates grown in vitro. Anat. Rec. 102, 71-81.

Pourtors, M. 1966. Onset of the acquired potentiality for fusion in the palatal shelves of rats. $J$. embryol. exp. Morph. 16, 171-182.

PourTors, M. 1968. La fusion des crêtes palatines et son alteration par quelques agents tératogènes. Archs Biol. (Liege) 79.

Reeve, W. L., PORTER, D. and Letkowitz, W. 1966. In vitro closure of the rat palate. J. dent. Res. 45, 1375-1380.

Sptvack, J. and Bennett, J. E. 1968. Glossopalatine ankylosis. Plast. Reconstr. Surg. 42, 129-136.

SteffeCK, A. J., KING, C. T. G. and DerR, J. E. 1966. The comparative pathogenesis of experimentally induced cleft palate. J. Oral Ther. Pharm. 3, 9-16.

SWENSON, E. A. 1926. The development of movement of the albino rat before birth. Thesis, University of Kansas (Unpublished).

Vargas, V. I. 1967. Palatal fusion in vitro in the mouse. Archs oral Biol. 12, 1283-1288.

VARGAS, V. I. 1968. Fusion of the palatine shelves with heterotype explants in the mouse. Archs oral Biol. 13, 845-848. 


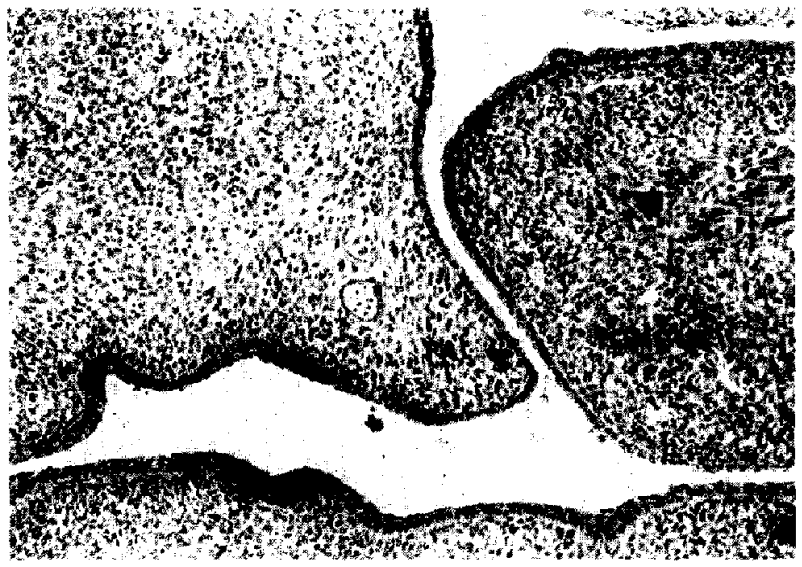

Fig. 1. In-vivo relationship between palatal shelf (PAL) and tongue. Age 15/16 days. $\times 40$

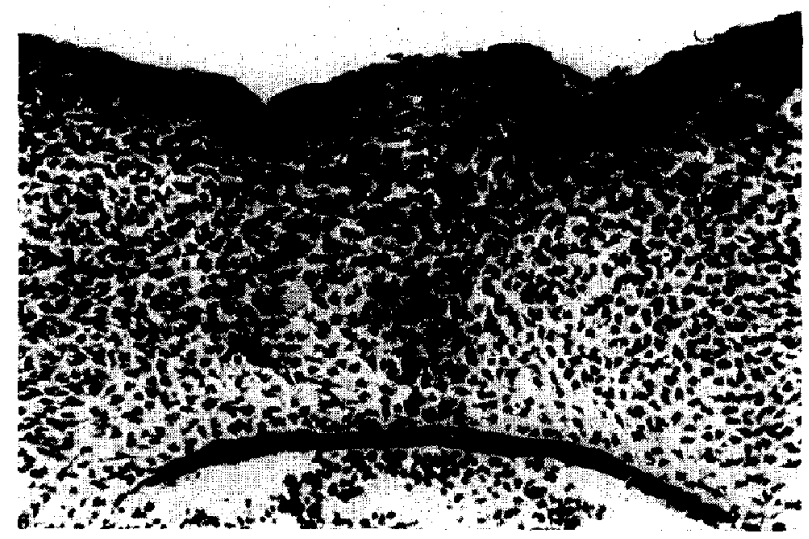

FIG. 6. Complete in-vitro fusion between palatal shelves. Oral surface uppermost. Haematoxylin and eosin. $\times 80$ 


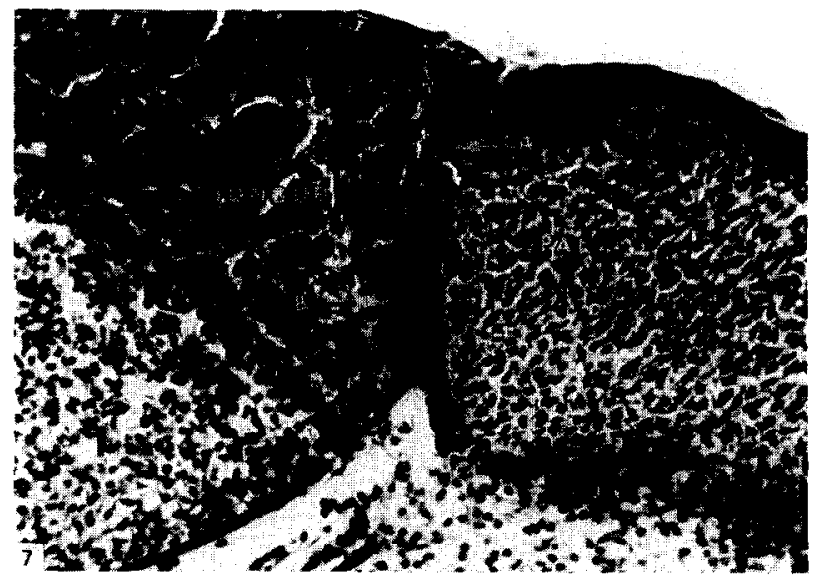

FIG. 7. Complete in-vitro fusion (A) between palatal shelf (PAL) and tongue. (B) shows laminated state. Haematoxylin and eosin. $\times 80$

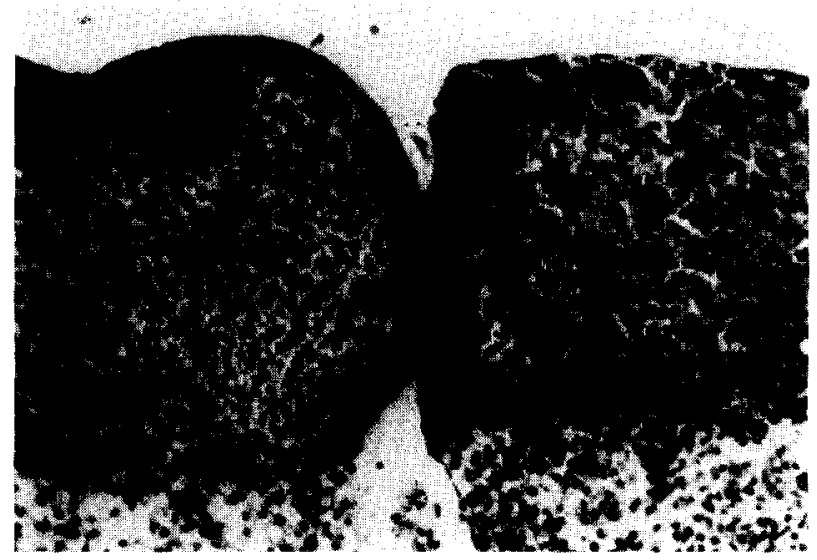

FIG. 8. Laminated in-vitro fusion (A) between palatal shelf (PAL) and tongue. Haematoxylin and eosin. $\times 80$ 


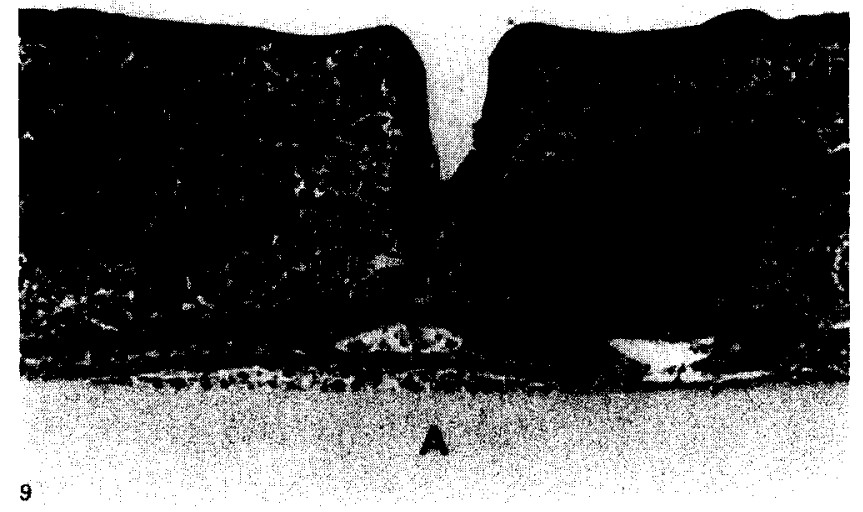

FIG. 9. Laminated in-vitro fusion between two tongues (B). Millipore filter at base (A). Haematoxylin and eosin. $\times 80$

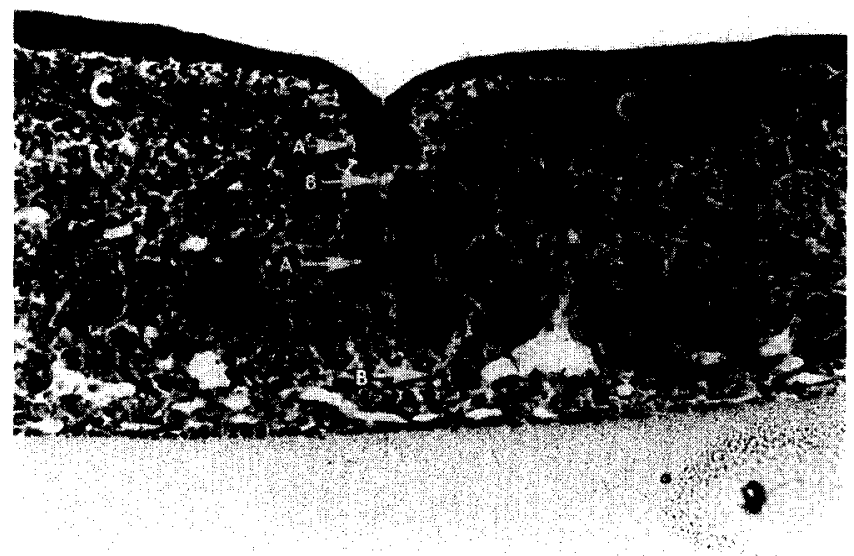

Frg. 10. Laminated in-vitro fusion between two tongues (A) with some penetration (B). Layer of muscle cells forming beneath epithelium (C). Haematoxylin and eosin. $\times 80$ 
A. N. Goss, J. W. Bodner and J. K. Avery

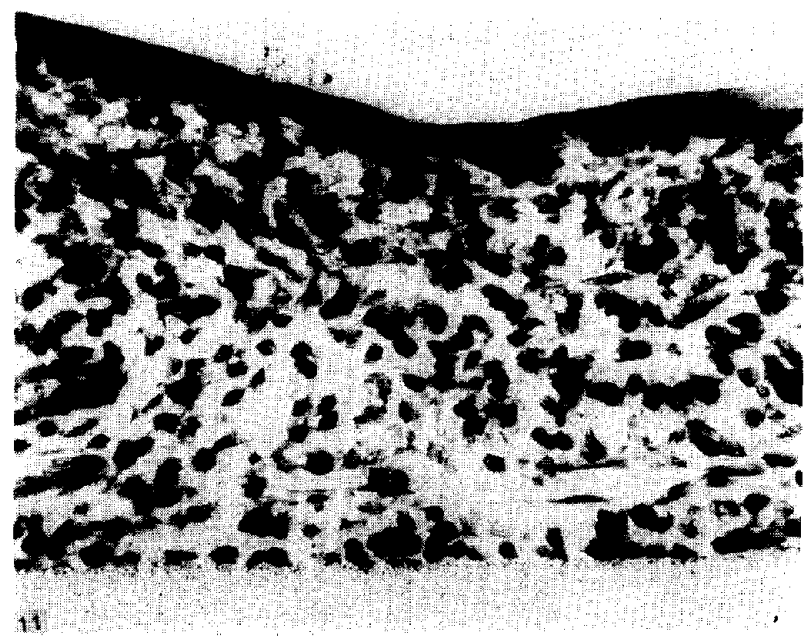

FIG. 11. Complete in-vitro penetration between two tongues. Haematoxylin and eosin. $\times 125$ 